\title{
Vuorovaikutusosaaminen ja kollaboratiivinen vuorovaikutus pk-yritysten kansainvälistymisessä
}

\author{
Pipsa Purhonen
}

Lectio praecursoria puheviestinnän väitöskirjaksi tarkoitetun tutkimuksen Interpersonal Communication Competence and Collaborative Interaction in SME Internationalization tarkastustilaisuudessa Jyväskylän yliopistossa 13.4.2012. Vastaväittäjänä toimi professori Leena Louhiala-Salminen (Aalto-yliopiston kauppakorkeakoulu) ja kustoksena lehtori Tarja Valkonen.

Työpaikan vuorovaikutusuhteisiin voi liittyä monenlaisia haasteita. Vaikka työpaikan vuorovaikutussuhteiden tulisi lähtökohtaisesti edistää organisaation etuja, liittyy niihin usein myös henkilökohtaisia odotuksia ja tavoitteita, jopa emotionaalinen side. Dynaamisessa ja yhä kansainvälisemmässä työelämässämme vuorovaikutussuhteet rajoittuvat vain harvoin organisaatioiden sisälle, vaan ne ylittävät organisaatioiden, toimialojen ja maantieteellisiäkin rajoja.

Väitöskirjatyöni tarkastelee sosiaalista vuorovaikutusta, työelämän vuorovaikutussuhteita ja niissä tarvittavaa vuorovaikutusosaamista suomalaisten pienten ja keskisuurten yritysten kansainvälistymisessä. Monelle pk-yritykselle kansainvälistymisestä on tullut tärkeä kilpailu- ja kasvutekijä, joillekin jopa elinehto. Suomalaiselle yhteiskunnalle yritysten kasvu ja kansainvälistyminen on puolestaan mahdollisuus kasvattaa osaamista ja vientiä sekä edistää maan työllisyyttä. Kansainvälistyviltä pk-yrityksiltä puuttuu kuitenkin usein rahoitusta, henkilöstöresursseja sekä kansainvälisille markkinoille etabloitumisessa tarvittavaa liiketoimintaosaamista, kuten markkinointi- tai verkostoitumistataitoja. Pk-yritysten kansainvälistymistyminen edellyttääkin erilaisia, niin kansallisia kuin kansainvälisiäkin, yhteistyösuhteita, joiden avulla yritykset voivat lisätä resurssejaan ja laajentaa yhteistyöverkostojaan.

Väitöstutkimukseni keskiössä on pk-yritysten ja kansainvälistymisessä keskeisten välittäjäorganisaatioiden, kuten alueellisten kehittämisyhtiöiden, teknologia- ja innovaatiokeskusten tai rahoitusorganisaatioiden, edustajien yhteistyö, jota lähestyn kahdenvälisenä sosiaalisena vuorovaikutuksena. Pelkästään työnjakoon perustuvan yhteistyön sijaan olen kiinnostunut kollaboratiivisesta vuorovaikutuksesta, johon liittyy jaettujen merkitysten ja yhteisen ymmärryksen rakentamista ja jolle on ominaista yhteistyökumppaneiden riippuvuus toisistaan sekä aktiivinen osallistuminen tehtävän suorittamiseen yhteisten tavoitteiden saavuttamiseksi. 
Tutkimuksellani oli neljä päätavoitetta, joista ensimmäinen oli kuvata ja jäsentää kollaboratiivista vuorovaikutusta pk-yritysten ja välittäjäorganisaatioiden edustajien yhteistyösuhteissa. Vaikka pk-yritysten kansainvälistymisen tutkimus on korostanut yhteistyökumppaneiden ja sosiaalisten verkostojen merkitystä kansainvälistymisessä, se ei ole syventynyt pohtimaan yhteistyösuhteissa tarvittavaa kollaboratiivista vuorovaikutusta. Kollaboratiivisen vuorovaikutuksen monitieteinen tutkimus on puolestaan tarkastellut yhteistyötä pääosin organisaatioiden tasolla, muttei ole juuri huomioinut interpersonaalisen, kahdenvälisen sosiaalisen vuorovaikutuksen merkitystä. Halusinkin tutkimuksessani selvittää sitä, millaisia käsityksiä ja kokemuksia yhteistyöhön osallistuvilla yksilöillä eli pk-yritysten ja välittäjäorganisaatioiden edustajilla on kollaboratiivisen vuorovaikutuksen luonteesta sekä yhteistyön mahdollisista esteistä ja ongelmista.

Toinen päätavoitteeni oli pohtia ja määritellä sitä, millaista vuorovaikutusosaamista kollaborativinen vuorovaikutus pk-yritysten kansainvälistymisessä edellyttää. Talouden globalisaatio on asettanut vaatimuksia elinkeinoelämän toimijoiden verkostoitumiselle ja yhteistyölle. Aiempi vuorovaikutusosaamisen tutkimus ei kuitenkaan ole pureutunut siihen, millaista vuorovaikutusosaamista yhteistyöosapuolet tarvitsevat organisaatio- ja toimialarajat ylittävässä yhteistyössä. Organisaatioiden väliseen yhteistyöhön voi liittyä esimerkiksi taustaorganisaatioiden erilaisia tavoitteita, vallan epätasapainoa ja kulttuurieroja, ja minulla olikin syytä olettaa, että kollaboratiivinen vuorovaikutus luo erityisen haasteen pk-yritysten ja välittäjäorganisaatioiden edustajien vuorovaikutusosaamiselle.

Kolmas tutkimustavoitteeni oli kehittää uusi vuorovaikutusosaamisen mittari ja testata sen soveltuvuutta kansainvälisen liiketoimintayhteistyön kontekstissa. Vuorovaikutusosaamisen mittaamisen traditio on vahva. Erilaisia vuorovaikutustaitoja, viestintämotivaatiota tai viestintään liittyvää tietoa ja ymmärrystä selvittäviä mittareita ja kyselyjä on kehitetty tusinoittain, kuitenkin pääasiassa puheviestinnän opetuskäyttöön. Mittaria, joka olisi koskenut nimenomaan liiketoimintayhteistyössä keskeistä vuorovaikutusosaamista ei vielä ollut. Neljäs tutkimustavoitteeni olikin käyttää tätä tarkoitusta varten kehittämääni vuorovaikutusosaamisen mittaria ja selvittää sen avulla pk-yritysten ja välittäjäorganisaatioiden edustajien vuorovaikutusosaamisen taso.

Näihin tavoitteisiin pyrin sekä laadullisen että määrällisen tutkimusaineiston avulla, jotka keräsin samanaikaisesti verkkokyselyllä keväällä 2009. Rajasin aineistonkeruun koskemaan erityisesti niitä yhteistyösuhteita, jotka ovat keskeisiä suomalaisten pk-yritysten kansainvälistyessä Kiinaan. Erilaisten arvioiden mukaan Kiinassa toimivia suomalaisyrityksiä on noin 280, joista pääosa on pieniä tai keskisuuria. Pk-yritysten ja välittäjäorganisaatioiden yhteistyö korostuu eritoten suomalaisyritysten pyrkiessä Kiinan valtaville markkinoille, jolloin välittäjäorganisaatioiden edustajat voivat auttaa yrityksiä luomaan tarvittavia 
yhteyksiä paikallisiin viranomaisiin sekä selviytymään kielivaikeuksista ja liiketoimintaympäristöjen eroavaisuuksien tuomista haasteista.

Tutkimushenkilöt, eli pk-yritysten ja välittäjäorganisaatioiden edustajat, tavoitin sähköpostitse erilaisten sähköpostilistojen ja jäsenluetteloiden perusteella. Lisäksi pyyntö osallistua tutkimukseen julkaistiin kolmella kansainvälistymistä käsittelevällä verkkosivustolla. Tutkimukseen osallistui 49 suomalaisten pk-yritysten ja 66 välittäjäorganisaatioiden edustajaa. Yhteensä vastaajia oli siis 115, joista valtaosa oli suomalaisia, mutta vastaajia oli myös Kiinasta, Ruotsista, Norjasta, Italiasta, Ranskasta ja Taiwanista. Aineistoa analysoin tilastollisin menetelmin sekä avoimiin kysymyksiin kirjoitettujen vastausten sisältöjä tulkiten. Tutkimusotteeni oli siis monimenetelmäinen.

Tutkimustulokseni perustuvat pk-yritysten ja välittäjäorganisaatioiden edustajien kuvailuihin kollaboratiivisen vuorovaikutuksen luonteesta sekä heidän antamiinsa arviointeihin, jotka koskivat yhtä, vastaajien itse valitsemaa yhteistyösuhdetta sekä heidän omaa ja yhteistyökumppaneidensa vuorovaikutusosaamista tässä kyseisessä vuorovaikutussuhteessa. Saavuttamani tulokset antavat moniulotteisen kuvan kollaboratiivisesta vuorovaikutuksesta pk-yritysten kansainvälistymisessä ja siinä tarvittavasta vuorovaikutusosaamisesta.

Tulosten perusteella pk-yritysten ja välittäjäorganisaatioiden edustajien kollaboratiivisella vuorovaikutuksella on erityisesti yhteistyön tuloksellisuuteen liittyviä tehtäviä, kuten tiedon jakaminen, ongelmanratkaisu ja uusien tuotteiden tai tiedon innovointi. Pk-yritysten ja välittäjäorganisaatioiden edustajat odottavat ja arvostavat myös suhdetason vuorovaikutusta ja viestintäeettisten periaatteiden noudattamista yhteistyössä. Vastaajien antamien kuvausten mukaan näitä tärkeitä periaatteita ovat esimerkiksi luotettavuus, avoimuus, rehellisyys, epäitsekkyys sekä erilaisuuden, kuten yhteistyöosapuolten kulttuuristen, organisatoristen ja ammatillisten taustojen, kunnioittaminen ja huomioiminen.

Pk-yritysten ja välittäjäorganisaatioiden edustajien kollaboratiivista vuorovaikutusta voidaan tutkimustulosteni perusteella hahmottaa yhteistyön tuloksellisuutta tukevana tehtäväviestintänä, vuorovaikutussuhdetta edistävänä ja ylläpitävänä relationaalisena viestintänä ja dialogisena viestintänä, jolla tarkoitan esimerkiksi jännitteisyyden ja moninaisuuden hallintaa ja viestintäeettisten periaatteiden huomioimista vuorovaikutuksessa. Yksi mielenkiintoisimmista tutkimustuloksista oli mielestäni se, että vastaajilla oli kuitenkin varsin erilaisia näkemyksiä siitä, missä määrin kutakin näistä kollaboratiivisen vuorovaikutuksen piirteistä tulisi painottaa liiketoimintayhteistyössä. Heillä oli esimerkiksi osin vastakkaisia odotuksia siitä, tulisiko yhteistyösuhteiden olla ennemminkin henkilökohtaisia vai ammatillisia vuorovaikutussuhteita.

Kollaboratiivisessa vuorovaikutuksessa voi tutkimustulosteni perusteella ilmetä lisäksi jännitteitä esimerkiksi suunnitelmallisuuden ja suunnittelemattomuuden tai pysyvyyden ja muutoksen välillä. Yhteistyösuhteita luodaan ja ylläpidetään strategisesti ja suunnitellusti, mutta uusia yhteistyömahdollisuuksia 
voi syntyä myös informaaleissa ja vapaaehtoisesti ylläpidetyissä vuorovaikutusverkostoissa. Yhteistyö edellyttää tarkasti määriteltyä suuntaa ja tavoitetta, mutta kansainvälisessä liiketoiminnassa kohdataan jatkuvasti odottamattomia muutoksia.

Näiden tutkimustulosteni perusteella esitän, että vuorovaikutusosaamiseen kollaboratiivisessa vuorovaikutuksessa pk-yritysten ja välittäjäorganisaatioiden edustajat tarvitsevat tietoa tehtäväviestinnästä, relationaalisesta viestinnästä ja dialogisesta viestinnästä sekä yhteistyösuhteisiin liittyvistä vuorovaikutussuhteen jännitteistä. Heillä tulee olla motivaatiota ja uskallusta edistää ja ottaa huomioon niin yhteistyön tehtävä- kuin suhdetason tavoitteita sekä halua noudattaa yhteistyön viestintäeettisiä periaatteita. Lisäksi he tarvitsevat vuorovaikutustaitoja kuten taitoa jakaa tietoa, tarjota instrumentaalista tukea, luoda, ylläpitää ja kehittää yhteistyösuhteita sekä hallita erilaisuutta tai yhteistyösuhteen jännitteitä.

Pk-yritysten kansainvälistymisessä keskeistä vuorovaikutusosaamista on sellainen vuorovaikutus, jossa yhteistyökumppanit keskittyvät yhteistyön tehtävätavoitteiden edistämiseen, mutta eivät välttele henkilökohtaisuutta vuorovaikutuksessa. He määrittelevät strategioita tavoitteiden saavuttamiseen, mutta ovat herkkiä myös ennakoimattomille yhteistyömahdollisuuksille sekä pyrkivät viestimään yhteenkuuluvuutta, mutta arvostavat toistensa erilaisuutta ja pyrkivät hyötymään siitä. Lisäksi he ovat aktiivisia vuorovaikutusosapuolia tehtävän suorittamisessa, mutta jatkavat yhteydenpitoa myös passiivisina ajanjaksoina sekä ovat päämäärätietoisia, mutta tarvittaessa joustavia yhteistyön toimintaympäristön muutoksissa.

Erityistä vuorovaikutusosaamista pk-yritysten ja välittäjäorganisaatioiden edustajilta vaaditaan kollaboratiivisen vuorovaikutuksen karikoiden välttämiseksi. Yhteistyön esteeksi voi tulosteni perusteella tulla esimerkiksi tehtäväviestinnän ja relationaalisen viestinnän riittämättömyys tai epätasapaino sekä viestintäeettiset ongelmat, kuten salailu, oman edun tavoittelu tai suoranainen epärehellisyys yhteistyössä. Pk-yritysten ja välittäjäorganisaatioiden edustajien mukaan viestintähaasteita voi nousta myös yhteistyön toimintaympäristöstä, kuten markkina-alueiden tai yhteistyöosapuolten taustaorganisaatioiden menettelytapa- ja kulttuurieroista. Pk-yritysten kansainvälistymisessä keskeisillä toimijoilla tulisikin olla ymmärrystä ja kykyä havaita näitä kollaboratiivisen vuorovaikutuksen mahdollisia ongelmia ja esteitä sekä halua ja vuorovaikutustaitoja selviytyä niistä yhteistyösuhteissaan.

Vuorovaikutusosaamisen mittarin kehittäminen ja pk-yritysten ja välittäjäorganisaatioiden edustajien vuorovaikutusosaamisen tason selvittäminen osoittautuivat haastaviksi tutkimustehtäviksi. Tulosten perusteella vuorovaikutusosaamisen taso pk-yritysten kansainvälistymisessä näyttää hyvin korkealta. Mielenkiintoista oli se, että pk-yritysten ja välittäjäorganisaatioiden edustajat arvioivat oman vuorovaikutusosaamisensa tason korkeammaksi kuin yhteistyö- 
kumppaneidensa. Ero oli tilastollisesti merkitsevä. Itsearvioinnit saattavatkin heijastaa yleistä viestintätyytyväisyyttä tai jopa väärää kompetenssia, jolloin viestijä pitää omana ansionaan sellaista, mikä ei sitä ole.

Sekä itsearviointien että yhteistyökumppanin arviointien perusteella pk-yritysten ja välittäjäorganisaatioiden edustajien vahvuuksia ovat erityisesti luottamuksen ja kunnioituksen osoittaminen kollaboratiivisessa vuorovaikutuksessa. Heikkoutena puolestaan voidaan pitää puutteita henkilökohtaisuuden ja tuttuuden osoittamisessa. On kuitenkin mahdollista, että henkilökohtaiseen tai relationaaliseen viestintään liittyviä vuorovaikutusosaamisen arviointituloksia vinouttavat erilaiset odotukset kollaboratiivisen vuorovaikutuksen luonteesta, erityisesti henkilökohtaisuuden ja ammatillisuuden välinen jännite.

Tilastolliset testit osoittivat kehittämäni vuorovaikutusosaamisen itsearviointimittarin ja yhteistyökumppanin arviointimittarin mittaavan jossain määrin eri asioita. Havaitsin myös, että vuorovaikutusosaamisen arviointituloksia voivat vinouttaa esimerkiksi myönteiset kokemukset laajemmista kansainvälistymiseen liittyvien tavoitteiden saavuttamisesta tai kokonaisvaikutelmat yhteistyösuhteesta ja -kumppanista. Arvioinnit ovat pikemminkin holistisia kuin analyyttisiä. Tulokset saattavat kertoa kollaboratiiviseen vuorovaikutukseen liittyvistä odotuksista ja arvostuksista ennemmin kuin pk-yritysten ja välittäjäorganisaatioiden edustajien vuorovaikutusosaamisen tasosta.

Tulosteni luotettavuutta olisi lisännyt suurempi tutkimusaineisto. Vuorovaikutusosaamisen mittarin kehittämistä olisi tukenut monimenetelmäisen tutkimusaineiston kerääminen vaiheittain, jolloin mittarin kehittämistyö olisi perustunut esimerkiksi haastattelu- tai havainnointiaineiston tuloksille. Verkkokyselyllä samanaikaisesti hankkimani laadullinen ja määrällinen tutkimusaineisto pikemminkin täydensivät kuin validoivat toisiaan. Monimenetelmäisyys mahdollistikin monipuolisen teoreettisen jäsennyksen kollaboratiivisesta vuorovaikutuksesta ja vuorovaikutusosaamisesta pk-yritysten kansainvälistymisessä.

Näkisin tutkimukseni tuloksista olevan käytännön hyötyä esimerkiksi elinkeinoelämän ja yhteiskunnallisille toimijoille, joiden työ ylittää maantieteellisiä tai organisaatioiden ja toimialojen rajoja. Tutkimukseni auttaa hahmottamaan organisaatioiden välistä yhteistyötä sosiaalisena vuorovaikutuksena sekä niitä haasteita, joita kollaboratiivinen vuorovaikutus ja sen mahdolliset karikot luovat yhteistyöosapuolten vuorovaikutusosaamiselle. Tuloksia voidaankin soveltaa niin yritysten kuin julkisen tai järjestösektorinkin toimijoille tarjotussa viestinnän koulutuksessa ja konsultoinnissa.

Vuorovaikutusosaaminen ja sen mittaaminen edellyttävät jatkotutkimusta työelämäkonteksteissa, joihin liittyy monenlaisia odotuksia vuorovaikutuksen luonteesta ja toisaalta vuorovaikutussuhteen ulkopuolelta tulevia viestintähaasteita. Erityisesti työelämän vuorovaikutussuhteiden jännitteitä ja niiden hallintaa tulisi selvittää yhä tarkemmin. 